\title{
Gender Patterns in Faculty Participation: A Decade of Experience at a Mid-sized University
}

\section{MAROUSSIA AHMED, MARGARET DENTON, JULIA S. O'CONNOR \& ISIK URLA ZEYTINOGLU*}

McMaster University

\begin{abstract}
This article examines the progress made at a mid-sized Ontario university in reducing gender differences in faculty participation and experience of participation in university administration, decision-making, teaching, research, and other professional activities. Based on a survey of female and male faculty and the report of a Task Force on the Integration of Female Faculty, a number of recommendations were to be implemented beginning in the 1992/93 academic year. Progress is examined in light of a commitment to integration based on the principles of inclusion, visibility of procedure, equitable treatment, and climate of support. The article concludes by discussing issues related to participation which have relevance beyond the specifics of this case.
\end{abstract}

* The authors are listed in alphabetical order. Parts of this paper are based on two internal reports prepared at the university studied here. Authors would like to thank colleagues who contributed to original reports, as well as the Vice-President, Assistant to Vice-President, Office of Analysis and Budgeting staff, and Employment Equity Manager for providing assistance in updating the data. The survey used for the basis of this study was partially funded by the Secretary of State. 


\section{RÉSUMÉ}

Cet article examine les progrès accomplis dans une université ontarienne dans élimination des discriminations sexuelles parmi les membres du corps professoral, d'une part quant à leur participation, d'autre part quant à la perception qu'ils ont de leur participation aux prises de décisions dans les domaines de l'administration, de l'enseignement, de la recherche et des autres activités professionnelles au sein de l'université. Une enquête auprès des membres hommes et femmes du corps professoral d'une université de taille moyenne constitue la base de données, à laquelle s'ajoutent des données supplémentaires recueillies subséquemment par un groupe de travail mis sur pied dans cette intention. Un certain nombre de recommandations basées sur ces travaux devaient être mises en vigueur durant l'année universitaire 1992-1993. Les progrès sont évalués en fonction des critères d'inclusion, de visibilité des procédures, d'équité dans la manière de traiter les individus, et du climat d'accueil apporté aux principes d'integration. Cette étude se termine par une discussion des aspects de la participation dont la pertinence dépasse les limites de cette étude.

Statistics indicate that in Canada, as elsewhere, women are the minority in tenured and tenure-track faculty positions and few are managers. They are found disproportionately at the junior ranks and in the part-time/sessional instructor positions (CAUT, 1997; Reynolds \& Young, 1995; Rosenblum \& Rosenblum, 1994). Previous studies have shown pay inequalities (Dean \& Clifton, 1994; Guppy, 1989) and discrimination in the hiring and tenure of female faculty (Rees, 1995). This is a feature of education systems, not only in Canada, but also in the USA, Europe, Australia, and in developing countries (Brooks, 1997; Eggins, 1997; Singh, 1998; Wilson, 1997).

In this paper we take a step beyond those issues and focus on gender differences in the participation of faculty in decision-making, administration, teaching, research, and other professional activities. The purpose of this paper is to analyze gender patterns in participation, and in the experience of participation over the $1988-98$ period in a mid-sized university. Results show that level of participation and the experience of participation are often different; a gap, and sometimes a chasm, separates them. 
We believe that our findings will contribute new knowledge on gender patterns in university faculty participation. Inclusion of the experience of participation conveys a more complex reality of participation than does an exclusive focus on level of participation, hence opening new avenues for action. In this paper, our goal is to place the findings in the changing context of the University's environment and discuss the findings and subsequent developments in light of four principles of integration: (1) inclusion, (2) visibility of procedures, (3) equitable treatment, and (4) climate of support.

We begin with a discussion of these four principles of integration followed by a brief literature review of factors that affect faculty participation. Following identification of data sources, we present the 1988 survey findings on gender patterns in faculty participation in practice (participation) and experience (perceived), the 1992-93 Task Force on the Integration of Female Faculty findings and recommendations, and updates of gender representation of faculty since the survey. We conclude with a discussion of our findings showing their relevance beyond the specifics of this case study university.

\section{PRINCIPLES OF INTEGRATION}

Integration, for all equity seeking groups, should be based on four principles: (1) inclusion, (2) visibility of procedures, (3) equitable treatment, and (4) climate of support (Task Force on the Integration of Female Faculty, 1990).

Inclusion means that all eligible candidates should be considered for positions of power, trust and prestige and that persons should be excluded only for cause. This means that formal non-discriminatory criteria should be the basis for selection and/or nomination for all positions. These are related to the chairing of $\mathrm{Ph} . \mathrm{D}$. defence, senior administrative positions and membership on various committees. The inclusion should not be based on mandatory membership of women in powerful committees, because of the perception of tokenism and the danger of overburdening a small number of women. However, qualified women who meet the necessary criteria for membership should be sought and included in significant decision-making committees. 
Visibility of procedures means that all faculty must have access to information about the making of decisions that affect their lives as members of the university community. For example, procedures relating to crucial decisions, such as those on merit pay, should not be obscure. The reporting of aggregate statistics on the implementation of such procedures is essential for the identification of problem areas.

Equitable treatment means that no assumptions based on gender stereotypes should be made about the interests and suitability of people for tasks. It involves equitable distribution of onerous or unpopular tasks as well as those that are prestigious or pleasant, equal access to information on policy and practice and equal recognition of the work and research interests of all faculty. Equitable treatment also relates to the evaluation of academic work, especially work in a new or unfamiliar area. For example, when a scholar's research interests diverge from the mainstream or challenge conventional positions, she/he may be at risk in the peer-review process. Consequently, to achieve equitable treatment in the evaluation of scholarship, experts in the relevant field should be consulted and when these are not available within the university they should be sought outside.

A climate of support denotes a work atmosphere of openness, fairness and support. Although the climate of an institution is often set from the top, the department is the key locale for faculty members. Consequently, the sensitivity of departmental chairs to the problems of integration of female and junior faculty is crucial for creating a climate of support. Such sensitivity implies recognition that the demands of family life may be different for men and women. For example, it is probable that more women than men are primary care givers; consequently meetings scheduled very early or late in the day may be more difficult for women to attend. Sensitivity also necessitates supportive career guidance for junior colleagues, men and women alike, security from harassment and the availability of remedies if this security is breached. 


\section{FACULTY PARTICIPATION AND FACTORS AFFECTING PARTICIPATION}

Faculty members participate in their universities through conducting three major tasks: research, teaching and administration/committee work. Research is an autonomous activity conducted alone or with colleagues that are in self-selected research teams. Teaching (as participation) includes graduate teaching and supervision as well as undergraduate teaching. Committees are the basic form of participation in decision-making in universities. At the departmental level, committees make recommendations to the Chair on issues such as tenure, promotion, hiring, and graduate and undergraduate education. At the faculty level, committees make recommendations to the Deans on such issues as tenure and promotion, graduate admissions, undergraduate and graduate education, awards and scholarships, and a host of other faculty level concerns. At the university level, committees include the Senate where issues related to the university as a whole are considered. Generally committee members are elected or appointed depending on procedures particular to each department, faculty or university committee. Other forms of participation include holding administrative positions and having joint or associate appointments (Denton \& Zeytinoglu, 1993).

Experience of participation is based on individuals' interpretation of their own employment histories and the experiences of their reference group. Experience of participation is not synonymous with participation, although the latter influences the former (Denton \& Zeytinoglu, 1993). Experience of participation refers to an interpretation of one's participation based on one's own and other's experiences. Participation may be more quantifiable, but it may, and often does, conceal effective participation, its range, degree and value. A woman may be appointed to a committee - participation - but the committee might be perceived as not important; a woman may be a member of a committee - participation - but perceive that she is not given attention because she is the only woman member; or a woman may have equal access to her Dean or a high level administrator, who most often happens to be a man, but current social practices constrain her from exercising this right.

A number of factors affect participation and experience of participation in universities. Universities act as typical internal labour markets, 
with controls for entry to various ranks, and promotion based on internal rules. As Smith (1975) notes, the structure of ranks, and admission procedures are powerful systems of professional control. Universities make rational decisions in appointments and choose only those with the best qualifications for the job. Applying Becker's (1975) human capital theory, we expect the participation and the experience of participation to be influenced by education level and job experience. Job experience is measured at universities by the number and type of academic publications, rank and teaching experience.

Another factor that might influence the experience of participation is the small percentage of female faculty relative to male faculty. Using Kanter's (1977) argument on representativeness, in numbers, in organizations, one can argue that women's acceptance in university participation will be lowest in faculties where there are few women and in ranks where there are few women.

Having mentors and networking influence one's experience of participation. Those that have strong mentors and are members of important networks are promoted to important positions in organizations (Burcke \& McKeen, 1994; Vinnicombe \& Colwill, 1995). Having a mentor and networking will influence faculty members' experiences of participation.

Research indicates that more men than women are assigned to tasks considered important for their organization (Goffee \& Nicholson, 1994; Vinnicombe \& Colwill, 1995). Developing firm-specific skills is one of the crucial factors for job security and promotion in internal labour markets (Dobbin, Sutton, Meyer, \& Scott, 1993). It is well known that historically in organizations, women were assigned to nurturing and caring jobs and men to challenging, problem solving jobs. In universities, influenced by societal gender-based beliefs, administrators often perceive female faculty to be more suited to undergraduate teaching, perceived to be a caring position, than to graduate training or membership in important committees, which are perceived to more challenging.

Harassment and discrimination are also factors used for controlling individuals (Zeytinoglu, Denton, Hajdukowski-Ahmed, \& O'Connor 1997), and female academics who are members of visible/ethnic minority face double barriers in the workplace $(\mathrm{Ng}, 1993)$. 


\section{DATA SOURCES}

This study uses three data sources: a 1988 survey to assess gender patterns in the participation of faculty and how this participation was experienced; a University level Task Force Report on the Integration of Female Faculty, which was issued in 1993; and data on gender representation in faculty since the survey and Task Force report. Each of these is discussed in the following sections.

\section{THE SURVEY OF FACULTY}

\section{Questionnaire Design}

In the Fall of 1988, with a grant from the State Secretariat, the Faculty Association's Status of Women Committee conducted a survey of faculty to assess gender patterns in the participation of faculty and how this participation was experienced. Questions referred to the participation of faculty in decision-making, administration, teaching, research, and other professional activities along with faculty members' experiences of their work environment. To find whether female and male faculty participated in proportion to their numbers in the university's administration, the survey included questions about their participation in committees and their election and/or appointment to administrative positions. The questionnaire did not include measures of job performance, such as the number of publications; rather the study assumes equal competence of faculty members at each rank. The draft questionnaire was pre-tested on twelve faculty members. These included males and females from different Faculties. Based on the results of the pre-test, and the comments of other faculty members, revisions were made to the questionnaire.

\section{Study Population and Sample}

The data on faculty employment status indicated that $14 \%$ of all faculty were female in the 1989-90 academic year - the year the survey results were reported - this excludes Health Sciences. ${ }^{1}$ The percentages of women in faculties ranged from $2 \%$ to $24 \%$. There was considerable variation across faculties and ranks: women were concentrated in the Humanities and Social Sciences Faculties and at the assistant professor 
and lecturer ranks. Women's representation was particularly low in Engineering, Sciences and Business Faculties, and at the full professor and associate professor ranks (Office of Analysis and Budgeting, 1997).

The survey covered all full-time female faculty (154) and a random sample of male faculty (232). Since the survey was originating from the Status of Women Committee, we anticipated a lower response rate on the part of some of the male faculty. Thus, male faculty members were over sampled for the study to ensure approximately equal numbers of females and males responding to survey. Although it may have been preferable to send the survey to all male faculty, budget constraints did not allow this option. A letter from the President of the University asking faculty members to participate in the study was included with each questionnaire. Usual surveying methods were used for the follow up. More than half of those surveyed returned their questionnaires and as predicted, more female faculty $(65 \%)$ than male faculty $(44 \%)$ responded. Of the males, assistant professors had the highest response rates.

\section{Characteristics of the Sample}

Responses to the survey showed that female faculty tended to be somewhat younger than male faculty - $31 \%$ females versus $21 \%$ males were under age 40 . Women also had fewer years of university teaching experience - 14 years of full-time teaching experience for females versus 17 years for males. Overall, more men (77\%) than women $(53 \%)$ were tenured; and $83 \%$ of female and $93 \%$ of male faculty held Ph.D. degrees. Faculty members were also asked the year in which they received their highest degrees. Proportionately more males $(45 \%)$ than females $(13 \%)$ received their highest degrees prior to 1970 , while proportionately more females $(52 \%)$ than males $(23 \%)$ received their highest degrees in the $1980 \mathrm{~s}$. This pattern reflects the greater proportion of males at the rank of full professor. In terms of rank, proportionately more of the male faculty members were at the rank of full professor $51 \%$ compared to $19 \%$ of female faculty - while proportionately more of the female faculty were assistant professors or lecturers - $48 \%$ compared to $21 \%$ of male faculty. About equal proportions of male and female faculty were associate professors $-28 \%$ and $33 \%$ respectively. 
In terms of sociodemographic characteristics, more female (31\%) than male (19\%) faculty were single, separated, divorced or widowed. Female faculty were more likely to indicate they were the primary person in their family with child-rearing responsibilities - $38 \%$ females compared to $7 \%$ males. A total of $16 \%$ of faculty identified themselves as a member of a visible or ethnic minority $-23 \%$ of males and $8 \%$ of females.

\section{Data on Participation}

The results suggested that in proportion to their numbers, female and male faculty were equally likely to be members of committees - about $78 \%$ and $73 \%$, respectively, for departmental committees; $38 \%$ and $46 \%$, respectively, for Faculty level committees; $18 \%$ and $26 \%$, respectively, for University level committees. There were no statistically significant differences in committee membership between males and females. Male and female faculty differed, however, in participation at the administrative level at all ranks. The data showed that men were more likely than women to have held an administrative position such as Departmental Chairs - 33\% males compared to $16 \%$ females (significant at $\mathrm{p}<.01$ level); Associate Chairs - 10\% males compared to 1\% females (significant at $p<.05$ level); Deans or Associate Deans - 5\% and 4\% which was not statistically significant); President and Vice-President of the University $-100 \%$ males. It should be noted that senior administrative positions in the University are decided by appointed ad hoc committees.

There were no significant gender patterns in the proportions who gave scholarly talks, held joint or associate appointment in another academic Department or Program, engaged in collaborative research with other members of the faculty or applied for research grants. Respondents said that Chairs or Deans consulted male and female members equally. Thus, we can state that our respondents, with the noteworthy exception of holding administrative positions, appeared to participate almost equally in the university.

In teaching, which is one of the three major tasks of university faculty, the survey respondents said that female faculty spent an average of 15 hours per week and male faculty spent an average of 17 hours per week teaching and advising students; this difference is not statistically significant. Graduate teaching and supervision are generally perceived as 
more rewarding and prestigious than undergraduate teaching. On this item there were differences between the experiences of men and women. At the graduate level, male faculty said that they spent on average more time than female faculty in teaching, advising and supervising students ( 4 hours versus 2 hours per week, significant at $p<.06$ level). Male faculty also tended to be more likely than their female counterparts to be asked to be an examiner or Chair of a Ph.D. defence in which they had not previously been involved - 50\% compared to $35 \%$ (significant at $\mathrm{p}<.06$ level). In addition, twice as many women as men said that they were required to teach summer and evening courses - $38 \%$ compared to $19 \%$ (significant at $\mathrm{p}<.05$ ) - while men were more likely to teach the regular fall and winter courses and during the day. Let us remember that of the males, assistant professors had the highest response rate to our survey.

\section{Experiences of Participation}

While approximate equality in reports of participation by women and men in the functioning and administration of the university was evident, the picture changed significantly when we addressed the question of experience of participation. More women than men were of the opinion that they were not fully participating in the University's decision-making. For example, more women than men believed that they were not given serious consideration for administrative positions in the University.

At the Faculty and University level, the experience of estrangement from the decision-making group increased. Female faculty members were more likely to say that they neither knew their Dean well nor did they feel supported by their Dean or Senior Administrators. In a study we conducted on experience of participation, our regression analysis (controlling for other variables), showed that female academics were much less likely than their male colleagues to feel that they participated (significant at $\mathrm{p}<.01$ level) (Denton \& Zeytinoglu, 1993). Academic rank, visible or ethnic minority status, and membership in networks were also significant $(p<.01$ level). Full professors, and to a lesser extent, associate professors were more likely than assistant professors or lecturers to experience participation in decision-making committees. Those who were members of networks at the university perceived themselves to be participating. 
Faculty members who identified themselves as visible or ethnic minority status were less likely than others (white, Anglo-Saxon majority) to feel that they participated in university's decision making bodies. The regression analysis also showed that there was no significant effect of the possession of a Ph.D. doctorate degree, the amount of teaching experience, the possession of tenure, having a mentor, or the proportion of female faculty in their Department or Programme.

Responses showed that both female and male faculty members believed that they were supported by their colleagues. Women, however, remarked that when they spoke up in a meeting, it was their female colleagues who paid attention to their views. Almost half of the women $(44 \%)$ were of the opinion that men had greater opportunity for career advancement, and a quarter of male respondents $(26 \%)$ concurred with that statement (significant at $\mathrm{p}<.01$ level).

When asked to state their opinion on tenure and promotion, and on the perceived fairness of salary and merit increases, female faculty stressed the difficulty women faced in obtaining tenure and/or promotion. About a quarter of female respondents agreed with the statement that women are less likely than men, of equal accomplishments, to be considered for tenure and promotion, and fewer than one in twelve male faculty concurred (significant at $p<.01$ level). Nineteen per cent of female faculty compared to seven per cent of male faculty also believed that if women were to appeal a negative tenure and/or promotion decision, they held less chances than men to win their appeal (significant at $\mathrm{p}<.05$ level). Referring to their own individual situation, fewer women $(54 \%)$ than men $(77 \%)$ within each rank considered that their opportunities for tenure were, or have been, as good as those of their male colleagues (significant at $\mathrm{p}<.01$ level).

On the subject of salary, referring to their 1988 salaries, female and male faculty expressed satisfaction $(57 \%$ versus $62 \%)$, but this was not the case with merit increases. While more than half of them felt their own merit awards were generally equitable, more than $75 \%$ of women and about $65 \%$ of men pointed to inequities in the distribution of merit awards in their departments (significant at $p<.05$ level). This indicates considerable disquiet with the overall merit award process.

A question on sexual harassment, which referred only to the previous academic year, was included. The definition of sexual harassment 
was adopted from the Council of Ontario Universities (1988) and reads as "any sexually related act, practice, comment or suggestion that interferes with an employee's job or job performance or threatens his or her economic livelihood." Five percent of female and 3\% of male respondents reported that they were sexually harassed (the difference between genders was not statistically significant). Furthermore, $28 \%$ of female and $13 \%$ of male faculty reported the occurrence of inappropriate remarks about their appearance and/or clothing made by colleagues of the opposite sex (significant at $\mathrm{p}<.01$ level).

All these findings were summarized in a report presented to the University Faculty Association. In summary, the report showed that many women considered themselves isolated from the centres of power and prestige in the institution and that their scholarly work was undervalued. It also demonstrated that they, along with many of their male colleagues, believed that decisions affecting their academic lives and their remuneration were taken according to principles and processes that are obscure. The fact that these findings relate not only to women but to men supports the view that if we correct practices that disadvantage a particular group, all members of the community will benefit from the improvement.

We now turn to the follow up to the survey report, the recommendations that emerged, and their implementation. We also ask what is the relevance of our work for other institutions?

\section{TASK FORCE ON THE INTEGRATION OF FEMALE FACULTY}

A report of the survey findings, along with a set of recommendations, were made available to Faculty and administrators and the Status of Women Committee. The report recommended that the University set up a task force to implement the recommendations. A workshop was organized by the Faculty Association to present the report and recommendations. The workshop was well attended by the Faculty and administrators.

In response to the report and workshop, a Task Force on the Integration of Female Faculty was set up jointly by the Administration and the Faculty Association. Its terms of reference were to examine the report, to develop policies and procedures to eliminate inequities in the treatment of female and male faculty and to reduce their dissatisfaction with the university. The composition of the Task Force was decided by 
the Administration and the Faculty Association. It had six members, three women and three men, representative of the Faculties/Schools and all levels of faculty from assistant professor to dean.

The Task Force began its work with the data from the integration report and collected additional information on the employment status of faculty from various offices within the University, such as the Office of Institutional Analysis, and from interested individuals (such as Director of Women's Studies). It reviewed several reports on the status of women in universities in Canada. It concluded that the problems identified at this University proved to be neither unique nor insoluble.

Four inter-related themes were identified in these reports: (1) the marked under-representation of female faculty; (2) the low level of integration of women faculty; (3) the issue of apparent versus real integration, that is, attempts to create the appearance of integration without increased representation; this was identified as imposing a disproportionate share of administrative work on a small percentage of female faculty; (4) the negative consequences of under-representation and poor integration not only for women within universities but for men and women at a wider societal level. The solutions proposed in these reports include not only specific policies relating to hiring and conditions of employment, such as employment and pay equity, parental leave, child care and sexual harassment but also involve perception and attitude changes (CAUT 1986, Council of Ontario Universities 1988, OCUFA 1989). Similar solutions were proposed by the Task Force. In addition, it identified four principles which should underlie policy and practice, and made several recommendations under each of these headings. We have outlined these principles above (See PRINCIPLES OF INTEGRATION). Before discussing the application of these principles, we discuss the integration and hiring practice issues identified by the Task Force.

\section{Integration and Hiring Practices}

The hiring practices at the University indicate that, with the exception of the Science Faculty, hiring of assistant professors in tenuretrack positions in the period $1985 / 6$ to $1989 / 90$ reflected to a large extent the available pool of graduates in their disciplines. However, when men and women applicants were compared, female Ph.D.s were hired less often than were male Ph.Ds. This was also evident in the 
overall high percentage of men with tenure. It was also noteworthy that very few of the 40 new full and associate professors appointed in the second part of the 1980s were women.

The Task Force concluded that if these patterns were maintained a considerable period of time would elapse before the gender distribution in senior ranks could be altered. It also pointed out that to increase numbers, particularly in some disciplines, the enrolment of women in doctoral programmes should be encouraged and their interest in academic careers should be fostered.

The Task Force analysis indicated that integration and hiring were linked. As long as women remained a small proportion of the total faculty complement, full integration would be impossible and to a large extent the integration achieved would be apparent rather than real and might in fact have negative consequences for women. Having a woman on every committee may give the appearance that practices are changing; but if the women are drawn from the same small pool, the integration may be more apparent than real. Pressure to serve on several committees is likely to have negative consequences for the research productivity and private lives of the women involved. Given the present employment situation there is a need for innovative solutions to the dilemma of small numbers of female faculty and a commitment to employment equity.

The Task Force argued that commitment to equitable hiring was compatible with and, in fact essential for, hiring the best possible candidate. While it rejected quotas and preferential hiring of women to any particular specified number of vacancies, it made several recommendations aimed at achieving equity in the hiring process at all levels. In addition, for example, it recommended that the Provost should include in her/his annual report to Senate, data on the percentage of women hired, by Faculty (and areas within the Faculty where feasible), by type of appointment, and by rank, to ensure that the hiring of women to tenuretrack positions does not fall below their proportion in the available pool.

\section{Recommendations and Principles Underlying Recommendations}

The Task Force made 31 recommendations in all. The recommendations were intended to change the practices and environment that gave rise to the gender differences in perceptions identified in the "Integration 
of Female Faculty at the University" report and the disparities identified in relation to employment status. While recognizing that no set of rules would achieve perfect integration, the Task Force argued that all regulations and procedures that might impact the relationships among faculty and between faculty members and administrators should embody principles that would foster collegiality and provide an environment in which good scholarship and good teaching would be recognized and rewarded. To this end it identified four principles discussed above to govern implementation: inclusion, visibility of procedures, equitable treatment, and climate of support.

While the emphasis of the Task Force's recommendations related specifically to the integration of women faculty, it noted that its recommendations could improve conditions for all faculty supporting the view that correcting practices that disadvantage disproportionately a particular group will benefit other members of the community.

\section{Changing Perceptions}

While employment statistics indicated problem areas, the Task Force pointed out that the overall problem was not one that lends itself to quantification. Consistent with the Integration of Female Faculty report and other Canadian reports published at that time (CAUT 1986, Council of Ontario Universities 1988, OCUFA 1989), the Task Force put considerable emphasis on attitudes toward women, the quality of the working environment and experience of integration. Further, it pointed out that the differences in employment status between women and men can be perceived as setting, as well as reflecting, the general attitudes on campus. It concluded that effective implementation of recommendations for change necessitated the recognition that there was a problem. For example, it noted that relevant information on gender patterns in employment status was relatively difficult to obtain, and the data were not collected in a way that would facilitate detailed analysis of gender patterns.

The Task Force report was submitted to the University's Committee on Management - Faculty Negotiations in November 1990. It was finally accepted unanimously by the University Senate in April 1992, and the recommendations were to be implemented with effect from the 1992/93 academic year. By then, four years had elapsed since the onset of the study. 


\section{THEN AND NOW: GENDER REPRESENTATION OF FACULTY SINCE THE SURVEY AND TASK FORCE REPORT}

As discussed at the beginning of this paper, women were $14 \%$ of total faculty in 1989-90 academic year, excluding Health Sciences faculty. Starting with 1990-91 academic year, the percentage of female faculty slowly increased each year, while the percentage of male faculty declined. According to data provided by the Office of Analysis and Budgeting (1997) of the University studied here, in 1992-93 academic year, the year the implementation of recommendations started, $16 \%$ of all faculty were women. In $1996-97$, this percentage increased to $18 \%$. This increase might be interpreted as an indication of equitable hiring practices, though it may also be due to the increased rate of retiring male faculty members particularly in the year 1995-96 when generous retirement packages were offered to those eligible, who were mostly men. Replacements were reduced to a trickle. The data show that between 1989-90 and 1996-97 academic years, total faculty numbers decreased from 613 to 516 , a decline of $16 \%$. For the same time period, total male faculty numbers decreased from 529 to 422 , a decline of $20 \%$, while total female faculty numbers increased from 84 to 94 which represents an increase of $11 \%$.

In the 1996-97 academic year, Engineering (1\%), Business (11\%), and Science $(13 \%)$ have the lowest percentage of female faculty. This is very unfavourably low compared with the available female candidates with Ph.D.s in these fields. At least for the last two decades, females with doctorate degrees earned in these fields are consistently higher than the universities' hiring records. For example, between 1993-94 and 1995-96 about 8-9\% of doctorates in engineering and applied sciences were women, about $33-37 \%$ of business and commerce doctorates were women, and about $19-21 \%$ of mathematics and physical sciences, about $35 \%$ of biology and $67-68 \%$ of psychology doctorates were women (CAUT, 1997).

In comparison with Engineering, Business and Science Faculties, in the 1996-97 academic year, Humanities (28\%) and Social Sciences $(28 \%)$ have a large minority of female faculty. Compared with the available pool of female Ph.D.s in these fields (CAUT, 1997), Humanities and Social Sciences still fall behind in hiring females. For example, in 
1993-94 and 1994-95 academic years, percentage of women with Ph.D.s were $45 \%$ and $40 \%$, respectively for Humanities, and $43 \%$ for both years for Social Sciences.

How does the university studied here compare to other Ontario Universities on the integration of female faculty? The progress made in the past ten years broadly reflects the situation observed in other Ontario universities. Focusing on the province's universities, the Council of Ontario Universities state that in 1985-1986:

. . women were $31.3 \%$ of total new appointments; by $1992-$ 1993 , this percentage has increased to $38.4 \%$. Although the percentage of female full professors has gradually increased from $5.7 \%$ of the total in $1985-1986$ to $9.7 \%$ in $1992-1993$, the most significant increase in women faculty is with the assistant professor category, an increase of 58\%. (COU, 1996)

If one looks at the breakdown by faculty, the concentration of female faculty remains the highest in the Humanities and Social Sciences, and between 1986 and 1996, the increase in Engineering, Business and Sciences is minimal or non existent (COU, 1996). The overall picture has remained the same, as:

... no matter what the discipline, women's participation declines from the bachelor's degree level through each level of graduate study. The percentage of women faculty is lower still. Even in discipline groups such as education and the humanities, where women have long been a majority of students at the undergraduate level, fewer than one-third of the full-time faculty in 1992-1993 were women. (COU, 1996, p. 4)

While overall this university is still lagging behind many others in terms of the representation of female faculty, the high percentage of women in tenure-track positions (45\%) is an indication of potential of future equitable participation at all levels.

We also attempted to examine faculty data at this University by gender and administrative responsibility. The Office of Analysis and Budgeting (1997) was helpful in generating data for us. However, the data are not perfectly reliable since they are not collected regularly nor is there an obligation to do so. Though reliable data might be gathered from the Human Resources Office, it would require manual coding by 
their office which was not feasible. Due to confidentiality concerns, files could not be opened to researchers. Thus, data provided here on academic administrative positions should be read with caution.

Focusing only on the Dean and Associate Deans positions, and again excluding the Health Sciences Faculty, one woman and eighteen men filled these positions in 1989-90. In 1992-93, the year the implementation of the recommendations started, they were filled by one woman and seventeen men. In the 1996-97 academic year, the number of women had increased to two and the number of men has decreased to thirteen.

To corroborate the patterns emerging from these data we examined the 1996 Employment Equity report of this University (Employment Equity Manager, 1996). While total faculty numbers and the distribution by gender were the same in both sources, the gender distribution in higher level positions was not perfectly comparable, due to different data coding and reporting requirements. Both sets of data, however, indicate that higher level academic administrative positions (Deans and above) were overwhelmingly held by men. Between 1990 and 1996, the University has its first, and only, woman President (for one mandate) and subsequently, a Vice-President for a two-year period. We should, however, note that having one or more women in very senior positions does not create an environment of participation. Furthermore, not all women, including those in important decision-making positions, are interested in creating an equitable environment for all qualified women, and not all men are interested in keeping the status quo in so far as it is an inequitable environment for women.

\section{DISCUSSION AND CONCLUSIONS}

The perceived barriers to integration, which gave rise to the study of integration and the Task Force Report and recommendations suggested systemic discrimination among other possible factors. Here we would like to emphasize the complexity of the phenomenon. According to the Supreme Court of Canada:

Systemic discrimination in an employment context is discrimination that results from the single operation of established procedures of recruitment, hiring and promotion, none of which is necessarily designed to promote discrimination. 
The discrimination is then reinforced by the very exclusion of the disadvantaged group because exclusion fosters the belief, both within and outside the group, that the exclusion was the result of "natural forces", for example that women "just cannot do the job". To combat systemic discrimination, it is essential to create a climate in which both negative practices and negative attitudes can be challenged and discouraged. (CAUT, 1996, p. 3)

Systemic discrimination is also defined as "indirect, impersonal and unintentional discrimination that is the result of inappropriate standards which have been built into the employment systems over the years" (Employment and Immigration Canada, 1985). The Royal Commission Report on Equality in Employment argues that systemic discrimination requires systemic remedies (Abella, 1984). The experience with employment equity in the US shows that under legal requirements equitable human resources processes can be achieved (Dobbin et al., 1993). Remedial measures of a systemic kind call for a revision of, and/or break with, long standing practices and attitudes which are not easily changed (Aisenberg \& Harrington, 1988; Caplan, 1993; Stalker, 1993).

Despite the acceptance of the Task Force's recommendations by the University Senate in April 1992, it could not be assumed that change would occur in a short period and without the assignment of accountability and consistent monitoring. With the objective of ensuring accountability, the Task Force identified the University body, office or office-holder that should have responsibility for the implementation of each recommendation.

\section{What happened to the recommendations ten years later?}

No new survey was conducted on the present state of integration of female faculty nor was there any formal study to assess the degree of implementation of the recommendations. We shall, thus, rely on institutional statistics and on our own knowledge of the situation.

The Task Force recommendation that "The Provost should report annually to Senate on the progress made on the various recommendations" has been implemented only once, in 1995, (Senate Secretariat, 1997) by the only female Vice-President, Academic in the history of the 
University. ${ }^{2}$ This recommendation is important as it enshrines the notion of public accountability in the implementation of the recommendations. In addition, this recommendation suggested that the progress report be published in the university newspaper. Neither this report, nor any other reports were published in the University newspaper, although the editor, in communication with the authors (University Newspaper, 1997) indicated interest in doing so, if such reports existed and if they were expected to publicize them. In 1998 information related to the participation of female faculty was published in the University newspaper for the first time. The Office of Analysis and Budgeting generates annual data on many aspects of University life including the faculty numbers disaggregated by gender, rank and age. These annual reports have restricted distribution, to the President, Vice-Presidents, Deans, Directors of Academic Programmes, and Department Chairs. Faculty members can have access to these reports if they know of their existence and only if an administrator gives permission. In our case, we were granted access to, and permitted to use the raw data presented in the most recent annual report by the Vice- President, Academic.

Recommendations pertaining to structures and practice of integration on decision-making committees, doctoral theses committees, speakers, publication of professional achievements appear to have been largely implemented. For example, the office of Graduate Studies in this university regularly issues an electronic distribution list of upcoming theses defences requesting volunteer examiners. Professional achievements are listed in faculty bulletins and in the university newspaper. However, one notes that at the level of important decision-making committees, there appears to be a two-tier system: the elected bodies such as the Senate can claim representation but are perceived to have largely a rubber-stamping function, whereas appointed ad hoc committees have an important decision-making mandate such as choosing new senior administrators. There is generally one appointed female faculty on such committees, which does not represent a guarantee of effective participation.

Efforts were made to implement recommendations pertaining to the visibility of procedures and the distribution of tasks. For example, the awarding of merit increase is based on a specific formulae proposed by the Faculty Association and is implemented. Recommendations referring 
to equitable treatment in the distribution of undergraduate and graduate teaching appear to be largely implemented. However, due to budgetary constraints, many newly hired faculty are contractually limited or sessional appointees with no choice of courses and no input in the governance of the institution.

The implementation of recommendations which pertain to fostering a "climate of support" and "an environment that nurtures and recognizes its members equally" are the most problematic. During the past several years, some faculty and staff in this university have created grassroots groups such as the "Equity Committee" which comprises women and employees with disabilities, and the "Rainbow Committee" which comprises ethno-culturally diverse employees, in order to raise awareness in the university about equity issues. This is in itself indicative of a perceived malaise in the area of equity within the University. We shall look later at the possible reasons for this malaise.

In summary, progress was made in the implementation of recommendations relating to visibility of procedures, in participation at the graduate teaching and supervision levels, and the number of female faculty has increased. Yet, progress is slow and despite the recommendation of reporting on progress on various recommendations to Senate and publicizing this widely within the university community, it is clear that monitoring of the implementation process will have to be ongoing. This raises several issues, which have relevance beyond the specifics of this case.

First, it appears that the integration of female faculty is considered to be an issue and is acted upon when women faculty take the primary responsibility for it. Action has been dependent on the presence of a woman committed to gender equality as Chair of the Status of Women Committee. In 1993, the Faculty Association abolished the Status of Women Committee and established a Human Rights Committee. The mandate of the new committee is to address issues of equal rights and opportunities, as well as issues involving harassment, discrimination, employment equity and the status of women (Faculty Association, 1997). Since its inception, this Committee has been active primarily on academic freedom issues (Faculty Association, 1997). The Human Rights Committee has not opened the integration of female faculty as a specific issue. 
The second issue that has relevance beyond this University is that this kind of monitoring and commitment to constructive change takes time and energy. This creates problems for junior faculty because of the pressures on their time related to tenure and promotion. Only a minority of women are prepared to involve themselves with these activities, thus the burden on them is very heavy. The problem here relates back to the fact that integration of female faculty is seen as a women's issue rather than a rights and a justice issue concerning all faculty, as it should be.

Third, the process of achieving integration may present a dilemma for women committed to equality. Specifically, there may be a conflict between the process of becoming acceptable for a position of influence and/or power and striving for change. In advocating change, one may be perceived as a threat and disqualify oneself from selection for committees perceived to be important by the university community at large. The commitment to change is often perceived as ideological and activist, whereas the commitment to the status quo is likely to be perceived as objective and professional.

Lastly, how can one change attitudes, in particular those of administrators and others in positions of influence and power? Changed procedures without supportive attitudes are likely to have limited effect. Furthermore, the notion of academic freedom may be used as an excuse for behaviour that goes against the spirit of recommended practices. The individualistic and competitive nature of academic work can also be associated with an unsupportive environment for those faculty outside the mainstream. This may be more the case now as universities have become "market places rather than places for people to interrogate existing knowledge and create new ones" $(\mathrm{Ng}, 1993, \mathrm{p} .198)$. This gets back to the issue of developing policies that apply to everyone and adhering to the principles of inclusion, visibility of procedures, equitable treatment, and climate of support as outlined by the Task Force Report. Commitment to these principles from the senior level of administration is crucial to an equitable environment. The overall objective must be to make all discriminatory behaviour unacceptable.

The fact that women are not well integrated into universities has wider societal implications, well captured in the following statement made by Dr. K. L. Fulton: 
What women learn about the subordination of women in the university, men also learn. . The university is a gate keeper for many of the decision making positions in our society; what the university teaches has a tremendous impact on our whole society. And the university teaches in more ways that the course syllabus (Fulton, 1989).

Sexual harassment policies, equity policies and human rights policies and procedures were put into place across the universities in the province during the past decade, including this institution (COU, 1996). However, financial constraints have frequently been identified as obstacles to changes and these are likely to continue to influence the possibilities for change in the foreseeable future. There is a visible change at the structural level, both in the province and this institution, which appears to stand somewhat in the middle. But this institution, like many of its counterparts has not succeeded yet in fostering a climate of integration. Despite an increase in the number of female faculty hired they are still poorly distributed through faculty ranks.

\section{Why such a slow progress?}

Reports, books and articles on the issue of female faculty integration and related issues published over the past decade give us insight as to the reasons why more change has not been made in this area. Those reports are remarkably consistent. It is our contention that barriers to progress listed in the literature are to be found to different degrees in all institutions, including the one studied here. Prentice (1996) presents a report on the preliminary research on what happened to all the reports written in the 1980s and what kind of difference it has made in institutions. Her first findings confirm her initial hypothesis:

. . . simultaneous with equity initiatives undertaken in good faith, there are concomitant institutional and individual practices which obstruct campaigns for visibility, recognition and power made by women, people of colour and other marginalized groups. (Prentice, 1996, p. 8)

Her words are echoed by Wylie (1995) in her review of literature on the subject and are supported by several other contributions (Carmen, 1991; The Chilly Collective, 1995; Drakich et al., 1990; 
Elliot, 1995; Gaskel \& McLaren, 1991; Marchak, 1996; Thomson \& Stark, 1996).

The "pipe-line"argument that not enough female doctoral students are available and that there will be an equal number of female and male professors only when there is gender balance at the graduate level has proven to be fallacious (Wylie, 1995). Thus, we have to look elsewhere for explanations for the slow progress. These have to do with "the cumulative effects of environmental factors: the pervasive culture of the workplace that women confront when they move through the academic pipe-line" (Wylie, 1995, p. 36), a culture that fosters a chilly climate for women faculty. The expression "chilly climate" has become at once a common metaphor and a field of research and this expression and its variants appear in almost all the literature in this area since 1988. Women may have become better organized and more vocal, and with concerned male colleagues, have made advances in certain areas, but one has to go beyond structures to understand the comparatively modest gains they have achieved. To understand what prevents a complete integration of women faculty we have to reach the deeper level of power relations, habitual thinking and practices, as well as: ". . . a host of subthe personal and social barriers which often operate below the level of awareness of both men and women ... whose pervasiveness and cumulative effects are ignored" (Wylie, 1995:38), but which feed systemic discrimination and cool the professional climate.

Several of the barriers to integration which have been identified in this study confirm findings in the literature. These include:

1. Stereotyping: Women's strengths and weaknesses may still be assessed differently than men's, revealing a double standard (Wylie, 1995, p. 39). An "assertive" female faculty can hesitate to express her opinion for fear of being labelled "aggressive". Even her professional identity is often treated differently by students and colleagues. For example, using the first name or "Ms, Miss, Mrs" for a female faculty and "Dr" for a male faculty is not uncommon.

2. Devaluation of women's scholarship, expertise and achievements, including devaluation of scholarship on women's issues or feminist theories: Devaluation diminishes professional 
credibility, can affect promotions and constitutes a barrier to integration (Feldthusen, 1995).

3. Recourse to the notion of "academic freedom": Using academic freedom to suppress women's and other minorities views has been consistently reported. It creates a favourable ground for backlash politics by protecting discriminatory discourses (Prentice, 1996; Wylie, 1995). The frequent appearance of this expression (COU, 1996), raises the concern that it may be indicative of an attempt at discarding gender discrimination as an issue before it has been dealt with. Academic freedom prevents sensitivity training for the purpose of fostering inclusivity which becomes then an individual option and protects "business as usual" (Prentice, 1996, p. 8). Through an ideologically charged semantic shift, disadvantaged groups became "special interest groups".

4. Dismissal of female faculty issues as exaggerations, constructions, manifestation of collective paranoia or time wasted that would be better spent on "real" scholarship: According to Feldthusen (1995, p. 289), the significance of gender as a factor in discrimination is denied and the plague of "genderitis" spread by activists is denounced by some male faculty, who also trivialize sexual harassment, intimidate female colleagues, or remain silent when they witness those behaviours. Such an attitude renders the reality, and the research on it, invisible. Suggestions for constructive change can thus be ignored or can be implemented selectively as a token gesture.

5. Marginalization: This includes marginalization of women, people of colour and other identified groups into relatively powerless positions while maintaining that the institution observes objective neutrality and is "colour blind".

6. Meritocracy: This is the belief that ascribed characteristics and biases associated with them do not play any role in evaluations and only merit affects decisions. Such a belief dismisses any concern related to possible discrimination as hostile to institution. 
7. Discrepancies between structural changes and their implementation: As Drakich (1991) suggests, there is a difference between having a policy in place and designing/implementing action strategy. While many universities have adopted equity or harassment policies, the literature reports difficulties encountered in their implementation.

8. Fear of losing power and lack of awareness among the "privileged": Feldthusen (1995, p. 283) suggests that males in power fear losing privileges. It can also be argued that the awareness of being privileged often constitutes the blind spot in the privileged mode of thinking. One would have to step outside of privilege to understand how it operates.

9. Budgetary constraints: These are also often identified as an external factor that slows down integration; for example, they limit the actions that can be planned and undertaken towards equity such as educational activities.

These beliefs and practices, which operate within a hierarchical mode of governance, make it difficult for concerned faculty to shake old structures and beliefs, especially in the case of junior faculty, who understandably often choose to devote their time to the consolidation of their careers. All faculty know the well documented professional cost of commitment to change. The overwhelmingly male administration may also play a "divide and conquer" game by appointing compliant female faculty as token members of their decision-making inner circles.

To those factors, we can add several techniques institutions employ to dismiss reports and stall the implementation of recommendations. They were identified by Prentice (1996, p. 8) which calls them "making haste slowly", for example when the institution deems it necessary to strike new committees to report on reports. "Institutional under-resourcing of equity" can also slow the process of equity building. The "protection of jurisdictional boundaries" by different offices protecting their mandate and territory is also a factor contributing to delay. Finally, the administration can dis-empower equity work when it allows equity offices to have only a consultative power. At a deeper level, one can link the slowness of inclusion with the difficulty of identifying and 
questioning an ideology that is perceived as objective and pervades structures, opinions and practices.

According to Smith (1991), ideology means that "Images, vocabularies, concepts, knowledge and methods of knowing the world are integral to the practice of power" (p. 233). Women have learned to live within structures and within an ideology that predated their inclusion. Changing those structures and the ideology that sustains them is difficult, because "the closer positions come to policy-making or innovation in ideological forms, the smaller the proportion of women" (Smith, 1991, p. 244).

Part of the ideological process of exclusion could include what is called "selective reality", which Elliott (1995) analyses as "a kind of collective neurosis in which we participate when confronted with structures of oppression we prefer not to acknowledge" (pp. 3-4). It can explain failures to change inequities, be they structural or systemic. The following remark, presented as a joke, by a male colleague constitutes an example of selective reality: "Our department includes $30 \%$ of women faculty, isn't it? This is more than half! This is more than enough." It denies inequity, expresses the dubious satisfaction that "one has done one's share" as well as trivializes the issue through the verbal form of the joke.

Finally, it is a "fait accompli" that universities have become corporations in structure (corporate ladder) and in culture (boardroom cultural practices and language), thus reinforcing what has been a traditional male professional territory. To create a professional structure that would be more inclusive of women and diverse university populations, Fulton (1991, pp. 61-71) proposes an "interactive circular" model of a "university as a universe", which renders obsolete the vertical hierarchical ladder and the gender dichotomy it supports. Spheres of activities and functions such as "faculty", "students", "public relations", "research", "administration" would intersect and create a process of exchange. Between those spheres circulates a flow of energy - as opposed to the will of power which will be used for the common good. Such a model would also facilitate alliances and collaboration between groups that share common interests and vision. It would also facilitate their integration, as dichotomies and power differentials - therefore potential marginalisation - would be erased, or at least considerably reduced. But, as Prentice (1996) suggests, the first step would be to legitimize research on institutional climate and inclusion in all our institutions. Inclusion would be greatly 
facilitated if the present trend of granting sessional appointments was to be reversed in favour of tenure - track appointments.

There is now an awareness that women's issues should be dealt concurrently with issues related to visible minorities, gay and lesbians, and persons with disabilities. This inclusion of diversity might have contributed to the reduction the salience of women's issues, but it was promoted by women faculty who are critical of the reports from the $1980 \mathrm{~s}$ which addressed women's issues only (Wylie, 1995). As a result, female faculty have created constructive alliances with those diverse groups.

In conclusion, the results of this study are relevant for other institutions. This study demonstrates and validates the importance of perceptions and their contribution to enriching quantitative information. As we know problems faced by female faculty are not specific this institution. We also have reasons to be even more concerned about this issue, in the context of the major structural changes universities are undergoing. According to Rosenblum and Rosenblum (1994) who have undertaken a study of part-time instructors in Ontario, those changes create a segmented and flexible labour-market, with the result that "both part-timers and non-tenure stream full-time appointments appear to be becoming increasingly important in contemporary universities" (p. 64). New managerial and employment policies affect younger Ph.D.s, particularly women, since research shows that "at each age, men obtain a far greater proportion of those jobs which are ports of entry to the internal labour market" (p. 62). It is our hope that the diffusion of our work will initiate similar studies on gender patterns in faculty participation and experience in other post-secondary educational institutions and show how the question of integration affects the entire career progress of female (and to a lesser degree male) faculty. If other studies corroborate our findings, a concerted action of policies and changes in attitudes would be in order, to ensure integration of all faculty for the benefit of institutions and society at large. 


\section{References}

Abella, R.S. (1984). Report of the Commission on Equality in Employment. Ottawa, ON: Ministry of Supply and Services.

Aisenberg, N., \& Harrington, M. (1988). Women of academe: Outsiders in the sacred grove. Amherst, MA: The University of Massachussets Press.

Becker, G. (1975). Human capital. New York, NY: National Bureau of Economic Research.

Brooks, A. (1997). Academic women. Abingdon, Oxon: The Society for Research into Higher Education \& Open University Press.

Burke, R.J., \& McKeen, C.A. (1994). Career development among managerial and professional women. In M.J. Davidson, \& R.J. Burke, R.J. (eds.). Women in management (pp. 65-79). London, UK: Paul Chapman, Publishing.

Caplan, P. (1993). Lifting a ton of feathers: A woman's guide to surviving in the academic world. Toronto, $\mathrm{ON}$ : University of Toronto Press.

Carmen, L. (ed.). (1991). Toward a new equality: The status of women in Canadian universities. Ottawa, ON: Social Science Federation of Canada.

CAUT. (1986). Policy statement on positive action to improve the status of women in Canadian universities.

CAUT. (1996). Status of Women Supplement. CAUT Bulletin, 43(4).

CAUT. (1997). Statistical profile. Status of women supplement, CAUT Bulletin, 44(4).

The Chilly Collective. (1995). Breaking anonymity: The chilly climate for women faculty. Waterloo, ON: Wilfred Laurier University Press.

Council of Ontario Universities (COU). (1988). The Committee on the Status of Women. Employment Equity for Women: A University Handbook. Toronto, ON: Council of Ontario Universities.

Council of Ontario Universities (COU). (1996). Status of women in provincially-assisted Ontario universities and related institutions. Toronto, ON: Council of Ontario Universities.

Dean, J., \& Clifton, R. (1994). An evaluation of pay equity reports at five Canadian universities. The Canadian Journal of Higher Education, 24(2), 87-114.

Denton, M., \& Zeytinoglu, I.U. (1993). Perceived participation in decisionmaking in a university setting: The impact of gender. Industrial and Labor Relations Review, 46(2), 320-331.

Dobbin, F., Sutton, J.R., Meyer, J.W., \& Scott, W.R. (1993). Equal opportunity law and the construction of internal labor markets. American Journal of Sociology, 99(2), 396-427. 
Drakich, J. (1991). Strategies for a new equality employment: Equity for women in Ontario universities. Toward a New Equality, 3-13.

Drakich, J., Smith, D., Stewart, P., Fox, A., \& Griffith, A. (1990). The status of women in Ontario universities. Toronto, ON: Ministry of Colleges and Universities.

Eggins, H. (ed.). (1997). Women as leaders and managers in higher education. Abingdon, Oxon: The Society for Research into Higher Education \& Open University Press.

Elliot, P. (1995). Denial and disclosure: An analysis of selective reality as resistance to feminist curriculum. Resources for Feminist Research, 24, 1-2.

Employment and Immigration Canada. (1985). Affirmative action: What is it all about? Ottawa, ON: Employment and Immigration Canada.

Employment Equity Manager. (1996, September 25). University Employment Equity Data Report.

Faculty Association. (1997, April 9). E-mail correspondence with the Executive Assistant.

Feldthusen, B. (1995). The gender wars: Where the boys are. In The Chilly Collective (eds.), Breaking anonymity: The chilly climate for women faculty, (pp. 279-312). Waterloo, ON: Wilfred Laurier University Press.

Fulton, E.M. (1991). Alternative administrative structures. Toward A New Equality, 61-74.

Fulton, K.L. (1989). Opening address: Taking Action - Women and the University. Proceedings from the Symposium on the Status of Women at the University of Manitoba, October 12-13, 1989.

Gaskell, J., \& McLaren, A. (eds.). (1991). Women and education, 2nd edition, Calgary, AB: Detselig.

Goffee, R., \& Nicholson, N. (1994). Career development in male and female managers - Convergence or collapse? In M.J. Davidson \& R.J. Burke (eds.), Women in management, (pp. 80-92). London, UK: Paul Chapman Publishing.

Guppy, N. (1989). Pay equity in Canadian universities, 1972-73 and 1985-86. Canadian Review of Sociology and Anthropology, 26(5), 743-758.

Kanter, R.M. (1977). Men and women of the corporation. New York, NY: Basic Books.

Marchak, P. (1996). Racism, sexism and the university. Montréal, QC: McGill/ Queens University Press.

$\mathrm{Ng}$, R. (1993). A woman out of control: Deconstructing sexism and racism in the university. In S. De Costell (guest editor), Against the grain: Narratives of resistance, special issue, Canadian Journal of Education. 18(3), 189-206.

OCUFA. (1989). Resource materials on hiring and retention of female faculty. 
Office of Analysis and Budgeting. (1997, April 18 \& 22). Unpublished data generated for the authors upon request.

Prentice, S. (1996). Addressing and readdressing chilly climates in higher education. CAUT Bulletin 43(4), Status of Women Supplement.

Rees, R. (1995). Systemic discrimination in a university. Women and leadership in Canadian education, 33-44. Calgary, AB: Detselig.

Reynolds, C., \& Young, B. (1995). Introduction. Women and leadership in Canadian education, xv-xvi. Calgary, AB: Detselig.

Rosenblum, G., \& Rosenblum, B.R. (1994). Academic labour markets: perspectives from Ontario. The Canadian Journal of Higher Education, 24(1), 48-71.

Senate Secretariat. (1997, April 9). E-Mail correspondence with the assistant secretary of Senate.

Singh, J.S. (1998). Women and management in higher education: A commonwealth project. ACU Bulletin of Current Documentation, 133, 2-8.

Smith, D. (1975). Ideological structures and how women are excluded. Canadian Review of Sociology and Anthropology, 12(4), 354-369.

Smith, D. (1991). An analysis of ideological structures and how women are excluded: Considerations for academic women. Women and Education, 233-257. Calgary, AB: Detselig.

Stalker, J. (1993). Review of Caplan Paula, Lifting a ton of feathers: A woman's guide to surviving in the academic world. The Canadian Journal of Higher Education, 13(3), 163-164.

Task Force Report, (1990).

Thomson, D., \& Stark, C. (1996). The roles and participation of women in social science associations in Canada, Final report. Ottawa, ON: Social Science Federation of Canada.

University Newspaper. (1997, April 9). E-mail correspondence with the Editor.

Vinnicombe, S., \& Colwill, N.L. (1995). The essence of women in management. London: Prentice Hall.

Wilson, M. (ed.). (1997). Women in educational management: A European perspective. London, UK: Paul Chapman Publishing.

Wylie, A. (1995). The contexts of activism on "climate" issues. In The Chilly Collective (eds), Breaking anonymity: The chilly climate for women faculty, (pp. 29-60). Waterloo, ON: Wilfred Laurier University Press.

Zeytinoglu, I.U., Denton, M., Hajdukowski-Ahmed, M., \& O'Connor, M. (1997). The impact of work on women's health: A review of recent literature and future research directions. The Canadian Journal of Women's Health Care, 8(2), 18-27. 
32 M. Ahmed, M. Denton, J.S. O'Connor, \& I.U. Zeytinoglu

\section{Notes}

1 This faculty has a somewhat different administrative structure than the rest of the university. For example, it includes both clinical and non-clinical faculty and some of the faculty are remunerated totally through clinical earnings. For these reasons, they were not included in the survey.

2 She left the university shortly after this to take up appointment as President of another university. 